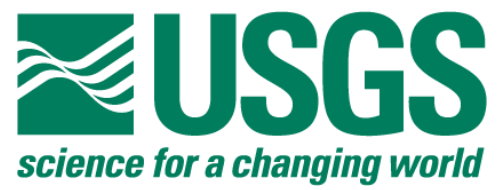

Examination of Libby, Montana, Fill Material for Background Levels of Amphibole from the Rainy Creek Complex Using Scanning Electron Microscopy and X-Ray Microanalysis

By David T. Adams, William H. Langer, Todd M. Hoefen, Bradley S. Van Gosen, and Gregory P. Meeker

Open-File Report 2010-1056

U.S. Department of the Interior

U.S. Geological Survey 


\section{U.S. Department of the Interior \\ KEN SALAZAR, Secretary}

\section{U.S. Geological Survey \\ Marcia K. McNutt, Director}

U.S. Geological Survey, Reston, Virginia: 2010

For product and ordering information:

World Wide Web: http://www.usgs.gov/pubprod

Telephone: 1-888-ASK-USGS

For more information on the USGS-the Federal source for science about the Earth, its natural and living resources, natural hazards, and the environment:

World Wide Web: http://www.usgs.gov

Telephone: 1-888-ASK-USGS

Suggested citation:

Adams, D.T., Langer, W.H., Hoefen, T.M., Van Gosen, B.F., and Meeker, G.P., 2010, Examination of Libby, Montana, fill material for background levels of amphibole from the Rainy Creek complex using scanning electron microscopy and X-ray microanalysis: U.S. Geological Survey Open-File Report 2010-1056, 10 p.

Any use of trade, product, or firm names is for descriptive purposes only and does not imply endorsement by the U.S. Government.

Although this report is in the public domain, permission must be secured from the individual copyright owners to reproduce any copyrighted material contained within this report. 


\section{Contents}

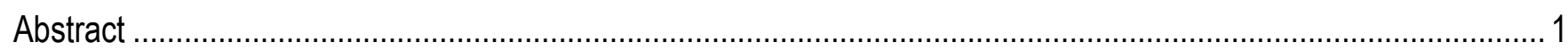

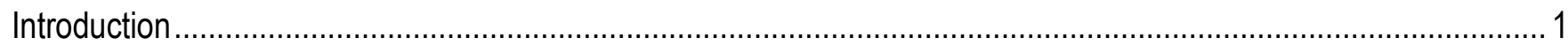

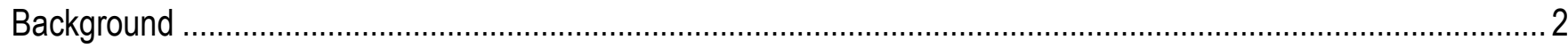

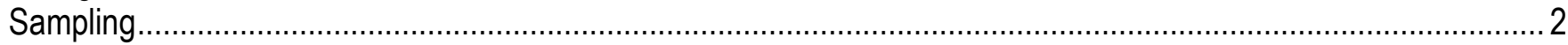

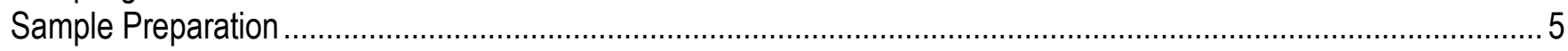

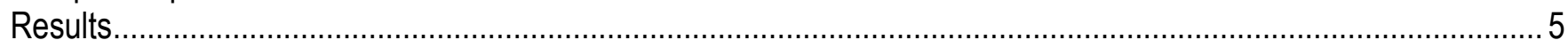

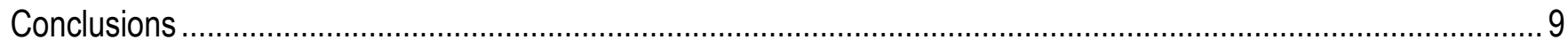

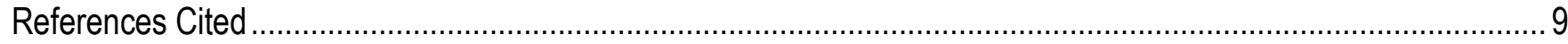

\section{Figures}

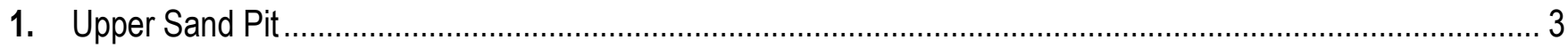

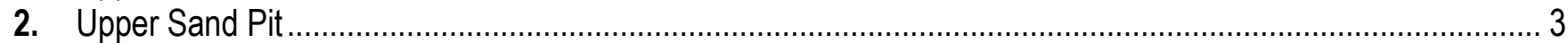

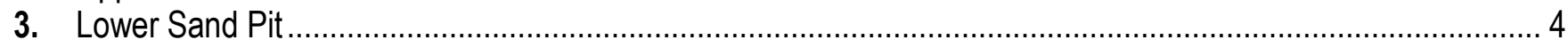

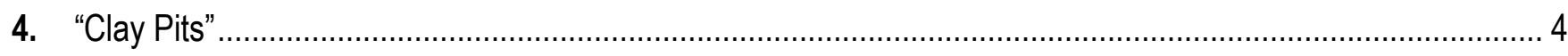

\section{Table}

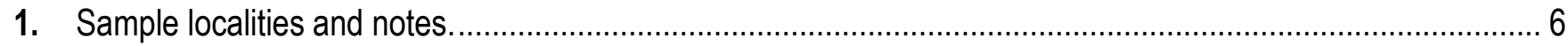




\title{
Examination of Libby, Montana Fill Material for Background Levels of Amphibole from the Rainy Creek Complex Using Scanning Electron Microscopy and X-Ray Microanalysis
}

\author{
By David T. Adams, William H. Langer, Todd M. Hoefen, Bradley S. Van Gosen, and Gregory P. Meeker
}

\begin{abstract}
Natural background levels of Libby-type amphibole in the sediment of the Libby valley in Montana have not, up to this point, been determined. The purpose of this report is to provide the preliminary findings of a combined U.S. Geological Survey and U.S. Environmental Protection Agency designed study to constrain the natural background levels of fibrous amphiboles potentially derived from the nearby Rainy Creek Complex. The material selected for this study was sampled from three localities, two of which are active open-pit sand and gravel mines. Seventy samples were collected in total and examined using a scanning electron microscope equipped with an energy dispersive $\mathrm{x}$-ray spectrometer. All samples contained varying amounts of feldspars, ilmenite, magnetite, quartz, clay minerals, pyroxene minerals, and non-fibrous amphiboles such as tremolite, actinolite, and magnesiohornblende. Of the 70 samples collected, only four had detectable levels of fibrous amphiboles compatible with those found in the Rainy Creek complex. The maximum concentraion, identified here, of the amphiboles potentially from the Rainy Creek Complex is 0.083 percent by weight.
\end{abstract}

\section{Introduction}

This Open-File Report provides preliminary findings of a study (U.S. Environmental Protection Agency, 2008) designed by the United States Environmental Protection Agency (EPA) and the U.S. Geological Survey (USGS). This report describes analytical results from samples collected from three localities in Libby, Mont. in June 2008 for the purpose of determining the local background levels of amphibole that could potentially be derived from the nearby Rainy Creek Complex (Boettcher, 1966, 1967). The amphiboles of interest were described in detail by Meeker and others (2003) and consist primarily of winchite, richterite, and tremolite based on the classification of Leake and others (1997). In this report we will refer to these amphiboles collectively as Libby-type amphibole (LA) for convenience.

The samples collected for the study represent the weakly consolidated sediments that were excavated from three Libby, Mont. sites from discrete layers of lake sediment deposited from glacial Lake Kootenai and Pleistocene terrace alluvium. These samples were analyzed to determine the background level of LA in the region, that is, the amount that could be attributed to prehistoric glacial 
processes. The background levels can help constrain the effects of anthropogenic contamination of soil with LA in the town of Libby and in surrounding areas. The results reported here are part of a larger study by USGS to constrain possible glacial contributions of Libby-type amphiboles to the region. The final report is currently in preparation for publication.

\section{Background}

The EPA Region 8 is conducting remediation activities to remove materials contaminated with fibrous and asbestiform amphibole derived from the former vermiculite mine located approximately 6 miles (mi) northeast of Libby, Mont. As part of that investigation, the EPA is determining background levels of LA and has requested the USGS to collect and analyze samples in the Libby area to determine if natural background levels of LA are present, which could be attributed to prehistoric glacial processes.

\section{Sampling}

In situ sampling took place in the sediment layers of two open pits (Sand Pit and Clay Pits) where sand and gravel material is actively mined. Sampling also was conducted in an undisturbed field (referred to as "Field") lying directly adjacent to Wooden Field, which was previously a source for fill material. In total, 70 samples were taken from discrete layers in the fill pit walls and from the Field. Many of these samples are shown in figures 1,2,3, and 4. Each sample was collected with a new, sterile, plastic sample scoop and placed into a clean plastic zip-top bag to prevent cross-contamination between sampled layers. For pit-wall samples, the surface of the outcrop was scraped back several centimeters to prevent surface contamination prior to collection. At the field location, the top-most organic layer (approximately 2 centimeters $(\mathrm{cm})(0.08$ inches (in)) was removed and discarded prior to sampling. Then a hole approximately 0.5 meters $(\mathrm{m})$ (approximately 1.6 feet $(\mathrm{ft})$ ) in diameter was dug using a narrow-bladed shovel and a stainless steel auger to a depth of 55 to $73 \mathrm{~cm}$ (22 to $29 \mathrm{in}$ ). The hole walls were scraped back several centimeters using a sterile hand trowel to remove any contamination prior to sample collection. All non-disposable field equipment was thoroughly decontaminated between each use. 


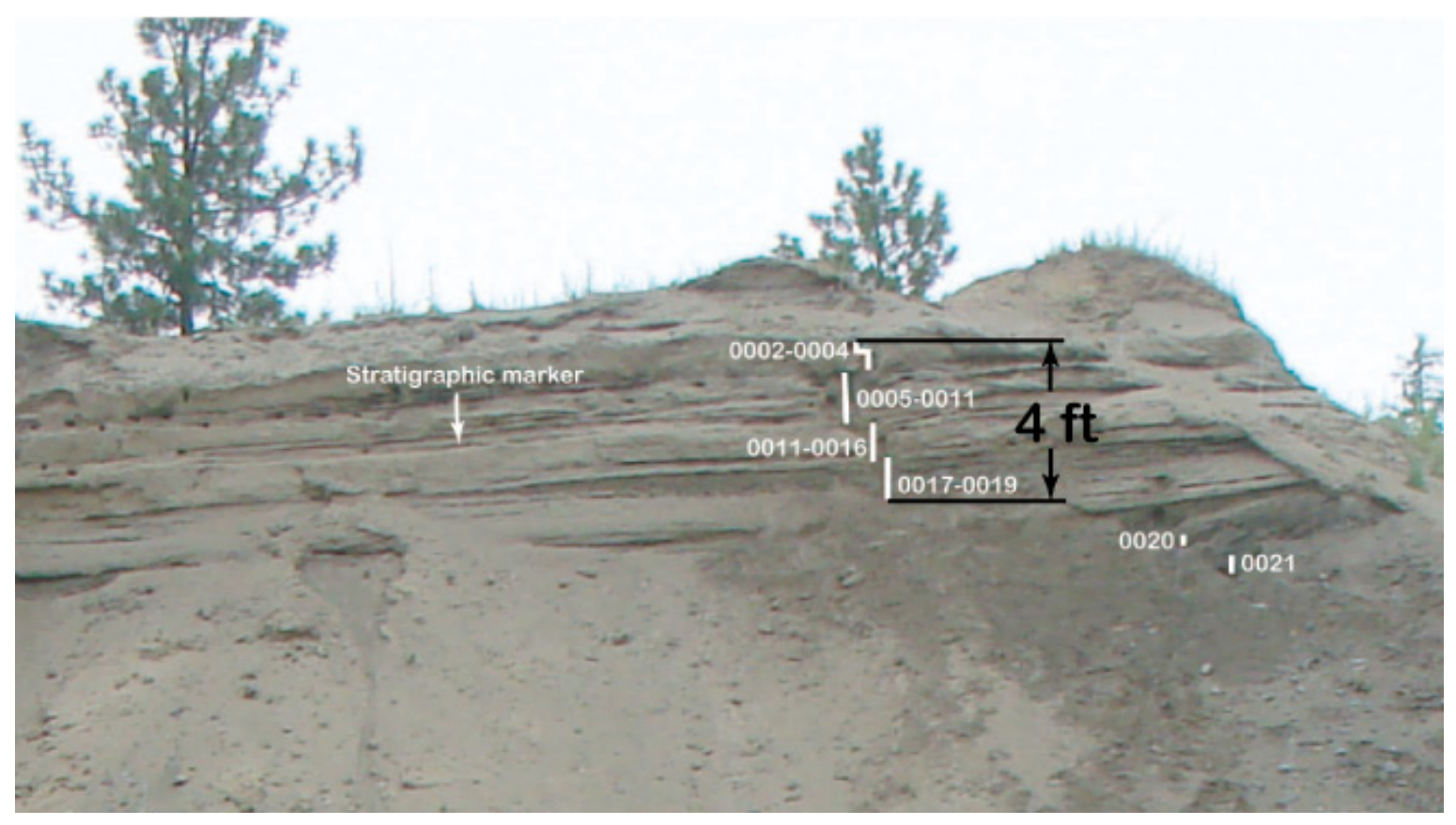

Figure 1. Upper Sand Pit. Samples 0002 through 0021 were obtained from this location.

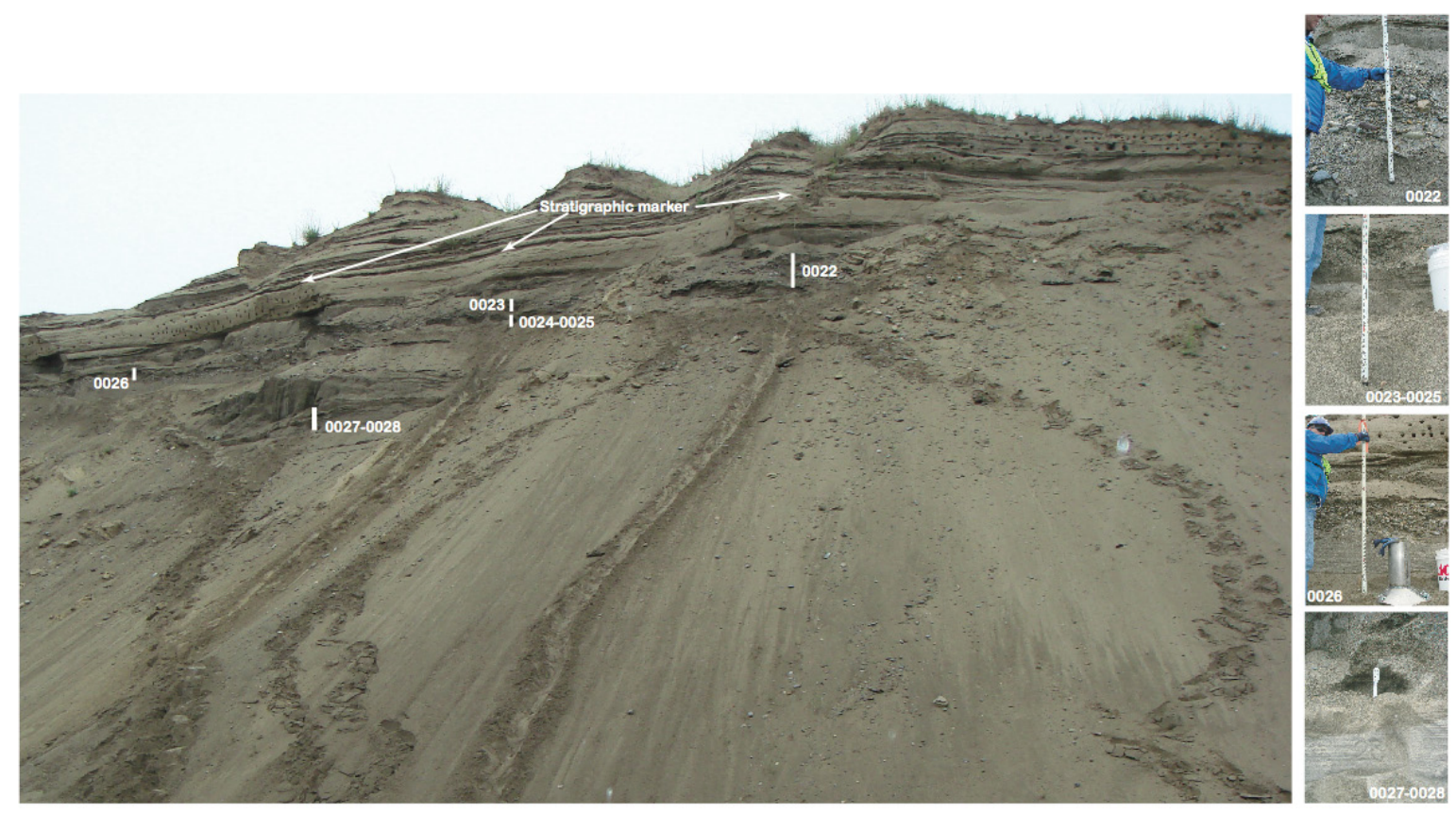

Figure 2. Upper Sand Pit. Samples 0022 through 0028 were obtained from this location. 

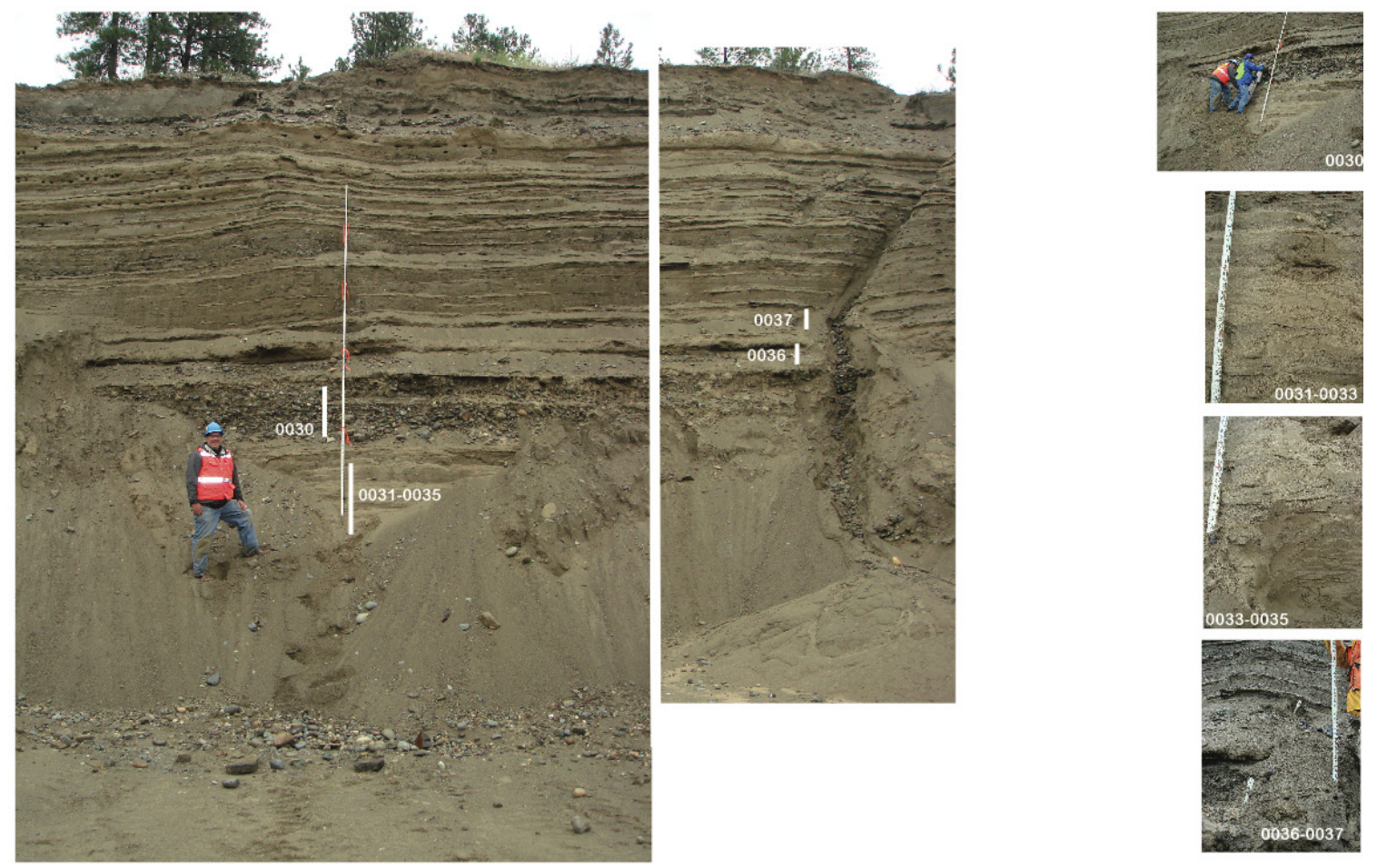

Figure 3. Lower Sand Pit. Samples 0030 through 0037 were collected at this location. Sample 0036 contains very low levels of $L A$ (See table 1).
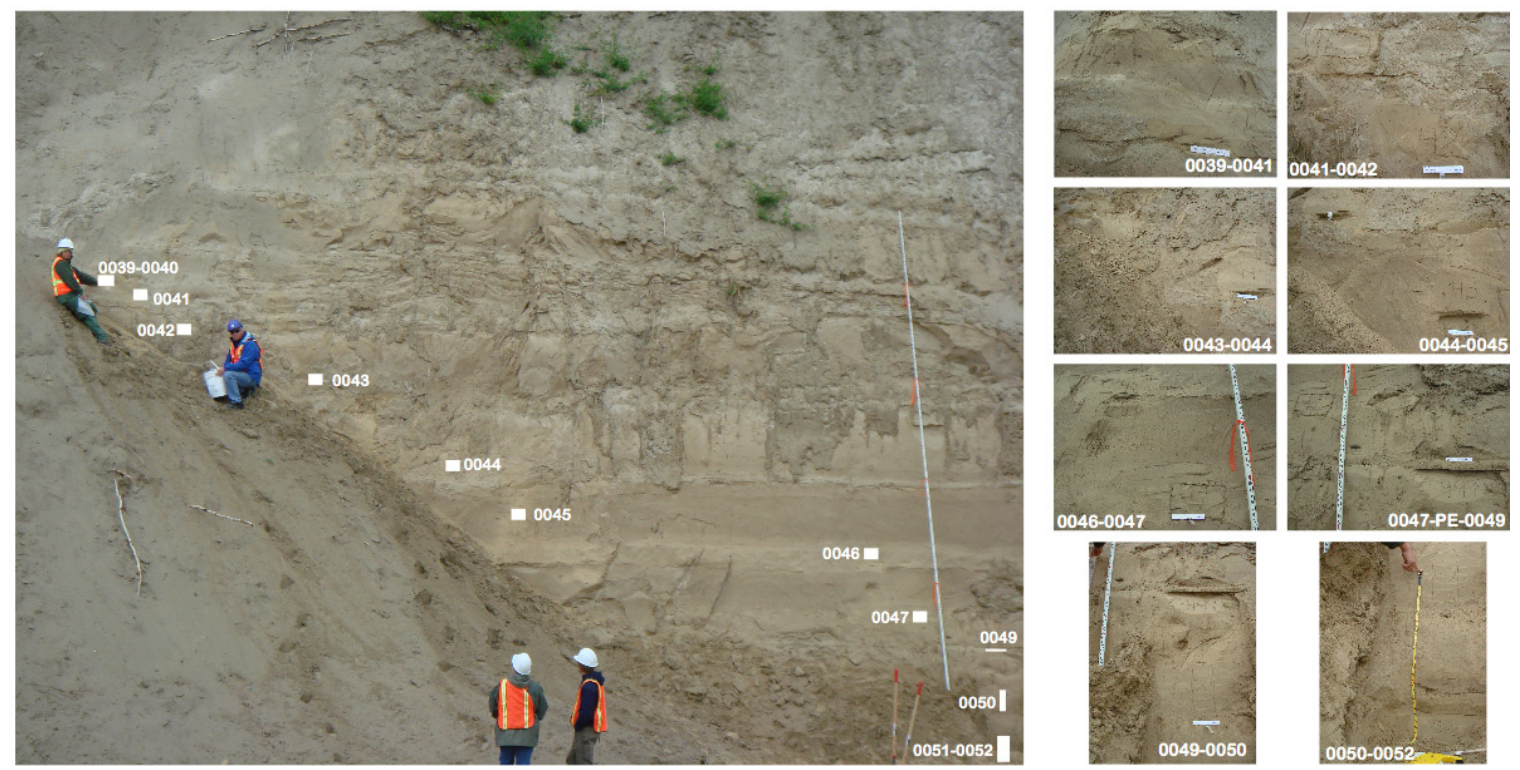

Figure 4. "Clay Pits". Samples 0039 through 0052 were collected at this location. LA was found to be present in samples 0049 and 0051 (See table 1). 


\section{Sample Preparation}

Samples were prepared using the methods described in Syracuse Research Corporation (2005) and are as follows:

- Drying: All of the samples collected were wet and required drying. To prevent crosscontamination, the samples were individually air dried in three fume hoods fitted with a HEPA (High-Efficiency Particulate Air) filter and stirred twice daily to facilitate drying. Minimum drying time was 3 days.

- Sample splits: Dried bulk samples were thoroughly mixed in their sampling bags by tumbling for 3 minutes ( $\mathrm{min})$. Each sample was then spilt using the cone and quarter technique (Gy, 1992); one of the quarters from each section was then sampled using a stainless steel spoon.

- Sample milling: Prior to milling any samples and between each sample, the ball mills were cleaned using several steps to avoid cross-contamination. Each mill was initially cleaned by milling quartz sand for 3 min and was then rinsed with isopropanol. After cleaning the mills, each was "pre-contaminated" with one heaping teaspoon of the sample, milled for $3 \mathrm{~min}$, then rinsed with isopropanol. Once the mill was pre-contaminated, 3 heaping teaspoons of material were placed into the ball mill and milled for 3 min to ensure the breakup of larger particles and to homogenize the material. Milled samples were placed into individually labeled zip-top bags. After each sample was milled, the ball mill was cleaned with quartz sand and rinsed with isopropanol.

- Scanning Electron Microscope (SEM) Mount Preparation: Approximately 0.50 grams (g) of each milled sample were weighed inside a HEPA-filtered fume hood. Each sample was diluted with 125 milliliters (mL) of deionized (DI) water in an $800 \mathrm{~mL}$ beaker while being continuously stirred by a magnetic stir bar. A 45 microliter $(\mu \mathrm{L})$ aliquot of the suspension material was extracted from the beaker with a $15-\mu \mathrm{L}$ pipette fitted with a $200-\mu \mathrm{L}$ pipette tip. The material suspension was seated onto a Whatman ${ }^{\circledR}$ Nuclepore $^{\mathrm{TM}} 25$ millimeter $(\mathrm{mm})$ diameter, 0.2 micrometer $(\mu \mathrm{m})$ pore size polycarbonate membrane filter using a Millipore $\AA$ filtration apparatus and hand pump to ensure even distribution onto the filter. The filter was attached to an aluminum SEM stub using high-purity, ultra-thin Nisshin ${ }^{\circledR}$ carbon tabs. Two SEM stubs were created for each sample and each SEM stub was coated with a thin layer of carbon in a carbon evaporator to ensure the conductivity of the sample while under an electron beam in the SEM.

\section{Results}

Results of the study, along with sample and locality descriptions and global positioning system (GPS) coordinates, are summarized in table 1. Photographs of sample locations and pit walls are shown in figures 1-4. All samples contained varying amounts of pyroxene, quartz, feldspar, clay minerals, ilmenite, magnetite, rutile, and non-fibrous amphiboles (aspect ratio less than 3:1) such as tremolite, actinolite, and magnesiohornblende. 
Table 1. Sample localities and notes.

[LA = Libby Amphibole, PE = Performance Evaluation, ND = Non-detect $]$

\begin{tabular}{|c|c|c|c|}
\hline Sample no. & $\begin{array}{l}\text { Height of center } \\
\text { of sample above } \\
\text { reference (ft) }\end{array}$ & Field description & Notes \\
\hline \multicolumn{4}{|c|}{$\begin{array}{c}\text { Upper Sand Pit \#1; } 10 \text { June 2008; N. 17594123.822 US ft; E. } 1991161.433 \text { US ft; Datum WGS 84, Zone } 11 \text { N; Reference Elevation } \\
\text { Bottom of stadia rod: } 2275 \mathrm{ft}\end{array}$} \\
\hline 0002 & 5.1 & Silty sand, cross bedded and ripples; root casts & \\
\hline 0003 & 4.8 & Silty sand, cross bedded and ripples; root casts & \\
\hline 0004 & 4.5 & Silty sand, cross bedded and ripples; root casts & \\
\hline 0005 & 4.3 & Silty sand, cross bedded and ripples; root casts & \\
\hline 0006 & 4.1 & Silty sand, cross bedded and ripples; root casts & \\
\hline 0007 & 3.9 & Silty sand, cross bedded and ripples; root casts & \\
\hline 0008 & 3.7 & Silty sand, cross bedded and ripples; root casts & \\
\hline 0009 & 3.6 & Silty sand, cross bedded and ripples; root casts & \\
\hline 0010 & 3.4 & $\begin{array}{l}\text { Silt and very fine sand, subhorizontal layers, each layer } \\
\text { about } 2-4 \mathrm{~mm}\end{array}$ & \\
\hline 0011 & 3.3 & $\begin{array}{l}\text { Silt and very fine sand, subhorizontal layers, each layer } \\
\text { about } 2-4 \mathrm{~mm}\end{array}$ & \\
\hline 0012 & 3.2 & $\begin{array}{l}\text { Silt and very fine sand, subhorizontal layers, each layer } \\
\text { about } 2-4 \mathrm{~mm}\end{array}$ & \\
\hline 0013 & 3.0 & $\begin{array}{l}\text { Silt and very fine sand, subhorizontal layers, each layer } \\
\text { about } 2-4 \mathrm{~mm}\end{array}$ & \\
\hline 0014 & 2.7 & $\begin{array}{l}\text { Silt and very fine sand, subhorizontal layers, each layer } \\
\text { about } 2-4 \mathrm{~mm}\end{array}$ & \\
\hline 0015 & 2.4 & $\begin{array}{l}\text { Silt and very fine sand, subhorizontal layers, each layer } \\
\text { about } 2-4 \mathrm{~mm}\end{array}$ & \\
\hline 0016 & 2.2 & $\begin{array}{l}\text { Silt and very fine sand, subhorizontal layers, each layer } \\
\text { about } 2-4 \mathrm{~mm}\end{array}$ & \\
\hline 0017 & 1.9 & $\begin{array}{l}\text { Silt and very fine sand, subhorizontal layers, each layer } \\
\text { about } 2-4 \mathrm{~mm}\end{array}$ & 17 \& 18: duplicate samples \\
\hline 0018 & 1.9 & $\begin{array}{l}\text { Silt and very fine sand, subhorizontal layers, each layer } \\
\text { about } 2-4 \mathrm{~mm}\end{array}$ & $17 \&$ 18: duplicate samples \\
\hline 0019 & 1.1 & $\begin{array}{l}\text { Silt and very fine sand, subhorizontal layers, each layer } \\
\text { about } 2-4 \mathrm{~mm}\end{array}$ & 1-ft section sampled \\
\hline 0020 & -1.0 & Coarse sand with few pebbles; dipping foreset beds & \\
\hline 0021 & -4.0 & Coarse sand with few pebbles; dipping foreset beds & \\
\hline
\end{tabular}

\begin{tabular}{|c|c|c|c|}
\hline \multicolumn{4}{|c|}{$\begin{array}{c}\text { Upper Sand Pit \#2; } 10 \text { June 2008; N. 17593942.723 US ft; E. } 1990995.142 \text { US ft; Datum WGS 84, Zone } 11 \text { N; Reference Elevation } \\
\text { Stratigraphic Marker } 3.1 \mathrm{ft} \text { above base of stadia rod }\end{array}$} \\
\hline 0022 & -3.2 & $\begin{array}{l}\text { Pebble cobble gravel with coarse sand; rounded to } \\
\text { subrounded; clast supported, no fabric, } 3 \mathrm{ft} \text { lens }\end{array}$ & Bulk sample \\
\hline 0023 & -4.5 & $\begin{array}{l}\text { Pebble cobble gravel with coarse sand; rounded to } \\
\text { subrounded; clast supported, no fabric, } 0.9 \mathrm{ft} \text { lens }\end{array}$ & $\begin{array}{l}\text { Bulk sample; } 40 \mathrm{ft} \text { south of Sample } \\
22\end{array}$ \\
\hline 0024 & -5.3 & Coarse sand, clean, massive & \\
\hline 0025 & -6.3 & Coarse sand, clean, massive & \\
\hline
\end{tabular}

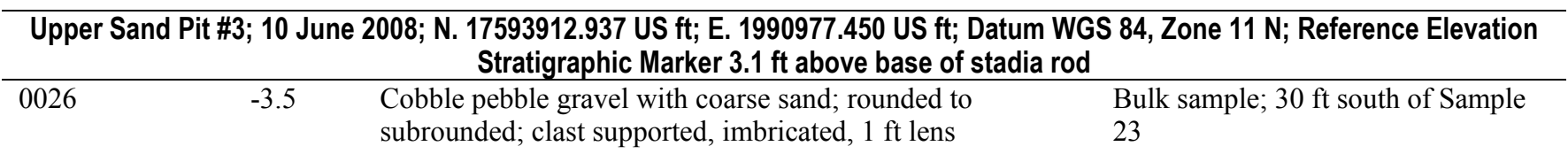


Table 1. Sample localities and notes.-Continued

\begin{tabular}{lcll}
\hline Sample no. & $\begin{array}{l}\text { Height of center } \\
\text { of sample above } \\
\text { reference }(\mathrm{ft})\end{array}$ & Field description & Notes \\
\hline 0027 & -9.0 & $\begin{array}{l}\text { Coarse sand with pebbles, clean, horizontal layers, } 2 \\
\text { mm thick; contains carbonized wood } \\
\text { Coarse sand with pebbles, clean, horizontal layers, } 2\end{array}$ & $\begin{array}{l}16 \mathrm{ft} \text { south of Sample 23; 20 ft below } \\
\text { mm thick }\end{array}$ \\
0028 & -10.0 & PE sample & \\
\hline
\end{tabular}

\begin{tabular}{lcll}
\hline \multicolumn{3}{c}{ Lower Sand Pit \#1; 10 June 2008; N. 17593553.394 US ft.; E. 1991723.413 US ft.; Datum WGS 84, Zone 11 N; Reference } \\
Elevation: 2177 ft
\end{tabular}

Clay Pits \#1; 11 June 2008; N. 17584475.745 US ft; E. 1996916.646 US ft; Datum WGS 84, Zone 11 N; Reference Elevation: 2128 ft

0038

0039

0040

0041

0042

0043

0044

\section{$20 \quad$ Clayey silt}

20 Clayey silt

18.5 Silty clay

17.0 Very fine sand, massive, iron concretions, fines upwards

15.5 Very fine sand, massive, iron concretions, fines upwards

11.0 Massive silt with granular concretions
PE sample

$39 \& 40$ duplicate samples

$39 \& 40$ duplicate samples

$8 \mathrm{ft}$ south of 0042

$6 \mathrm{ft}$ south of 0043

Clay Pits \#2; 11 June 2008; N. 17584458.567 US ft; E. 1996916.373 US ft; Datum WGS 84, Zone 11 N; Reference Elevation: 2128 ft

\begin{tabular}{|c|c|c|c|}
\hline 0045 & 8.5 & $\begin{array}{l}\text { Very fine sand, trace of silt, massive; numerous } \mathrm{CaCO}_{3} \\
\text { concretions }\end{array}$ & $3 \mathrm{ft}$ south of $0044 ; 18.5$ north of rod \\
\hline 0046 & 6 & Sandy silt, massive & $2.5 \mathrm{ft}$ north of rod \\
\hline 0047 & 3.6 & Silt to very fine sand; turbidity layer & $1 \mathrm{ft}$ north of rod \\
\hline 0048 & & & PE sample \\
\hline
\end{tabular}


Table 1. Sample localities and notes.-Continued

\begin{tabular}{|c|c|c|c|}
\hline Sample no. & $\begin{array}{l}\text { Height of center } \\
\text { of sample above } \\
\text { reference }(\mathrm{ft})\end{array}$ & Field description & Notes \\
\hline \multicolumn{4}{|c|}{ Clay Pits \#3; 11 June 2008; N. 17584437.828 US ft; E. 1996918.196 US ft; Datum WGS 84, Zone 11 N; Reference Elevation: 2128 ft } \\
\hline 0049 & 2.2 & Clay layer, 2.25 in thick & $\begin{array}{l}2.5 \mathrm{ft} \text { south of rod; } \\
\text { LA: Lower bound: } 0.023 \% \text {, } \\
\text { Upper bound: } 0.050 \%\end{array}$ \\
\hline 0052 & -2.7 & Clay, silty; massive & $2.5 \mathrm{ft}$ south of rod \\
\hline
\end{tabular}

Number in Ht. column for Field samples is sample interval in inches below reference elevation.

Field \#1; 11 June 2008; N. 17590529.663 US ft; E. 1987980.432 US ft; Datum WGS 84, Zone 11 N; Reference Elevation Land

\begin{tabular}{|c|c|c|c|}
\hline \multicolumn{4}{|c|}{ Surface Datum (LSD): $2070 \mathrm{ft}$} \\
\hline 0053 & $0-2$ & Organics & \\
\hline 0054 & $2-4$ & Cobble pebble gravel; A horizon & \\
\hline 0056 & $9-13$ & Cobble pebble gravel; B horizon & \\
\hline 0057 & $13-14$ & Cobble pebble gravel; B horizon & \\
\hline 0059 & $18-20$ & Cobble pebble gravel; $\mathrm{B} / \mathrm{C}$ horizon transition & \\
\hline 0060 & & & PE sample \\
\hline 0061 & $20-22$ & Cobble pebble gravel; $\mathrm{B} / \mathrm{C}$ horizon transition & $\begin{array}{l}\text { LA: Lower Bound } 0.004 \% \text {, } \\
\text { Upper bound: } 0.047 \%\end{array}$ \\
\hline
\end{tabular}

Field \#2; 11 June 2008; N. 17590457.826 US ft; E. 1987988.022 US ft; Datum WGS 84, Zone 11 N; Reference Elevation LSD: 2070 ft

$0063 \quad 0-4 \quad$ Organics / A horizon

0064

0065

4-7

Cobble pebble gravel; B horizon

No sample taken

0066

$7-10$

Cobble pebble gravel; $\mathrm{B}$ horizon

0067

$10-13$

Cobble pebble gravel; B horizon

0068

13-16

Cobble pebble gravel; B horizon

$67 \& 68$ duplicate samples

0069

13-16

Cobble pebble gravel; $\mathrm{B}$ horizon

0070

$16-29$

Cobble pebble gravel; $\mathrm{B} / \mathrm{C}$ horizon transition

Field \#3; 11 June 2008; N. 17590388.160 US ft; E. 1988008.336 US ft; Datum WGS 84, Zone 11 N; Reference Elevation LSD: 2070 ft

$\begin{array}{lcl}0071 & 0-2 & \text { Organic } \\ 0072 & 2-6 & \text { Cobble pebble gravel; A horizon } \\ 0073 & 6-14 & \text { Cobble pebble gravel; B horizon } \\ 0074 & 14-16 & \text { Cobble pebble gravel; B horizon } \\ 0075 & 16-19 & \text { Cobble pebble gravel; B/C horizon } \\ 0076 & 19-22 & \text { Cobble pebble gravel; B/C horizon }\end{array}$


Of the 70 samples collected and analyzed, only four samples contained amphibole compatible with amphibole derived from the once-active mine area of the Rainy Creek Complex (see Figure 6, Meeker and others, 2003). The detected LA was, in all cases, less than 0.1 percent by weight. The Sand Pit contained only one layer with detected LA and it is located in the lower portion of the pit in a clayey silt layer (elevation 2,286 ft). Two samples (elevations 2,126 ft and 2,130 ft) from the Clay Pits contain LA; these samples also came from the lower portion of the sampled wall at the base of the exposed cliff face and range in LA concentrations from non-detect to 0.05 percent (table 1). The final sample containing LA is from the Field, adjacent to the Wooden Field, where fill soil had been previously quarried. The sample containing LA from this locality was 20-22 in. below the surface and was at a concentration ranging from approximately 0.004 percent to approximately 0.047 percent by weight.

\section{Conclusions}

Seventy samples representing discrete individual stratigraphic layers were collected from three localities in or near the city of Libby, Mont. Each sample contained varying amounts of feldspars, ilmenite, magnetite, quartz, clay minerals, pyroxene minerals, and non-fibrous amphiboles such as tremolite, actinolite, and magnesiohornblende; this mineral assemblage is expected from the geology of this region. In general, background levels for LA are below detection limit except in four samples (Samples 0036, 0049, 0051, 0061). Measured concentrations of LA were: 0.059 percent to 0.082 percent at 2,186 ft elevation from the Lower Sand Pit; non-detect to 0.037 percent at 2,126 ft elevation; and 0.023 percent to 0.050 percent at $2,130 \mathrm{ft}$ elevation from the Clay Pits; and 0.004 percent to 0.047 percent at 22 in below $2,070 \mathrm{ft}$ elevation.

\section{References Cited}

Boettcher, A.L., 1966, Vermiculite, hydrobiotite, and biotite in the Rainy Creek Igneous complex near Libby, Montana: Clay Minerals, v. 6, p. 283-297.

Boettcher, A.L., 1967, The Rainy Creek alkaline-Ultramafic igneous complex near Libby, Montana, part I-Ultramafic rocks and fenite: Journal of Geology, v. 75, p. 526-553.

Gy, P.M., 1992, Sampling of heterogeneous and dynamic material systems-Theories of heterogeneity, sampling, and homogenizing: Amsterdam, The Netherlands, Elsevier Science Publishers B.V., p. 413-414.

Leake, B.E., Woolley, A.R., Arps, C.E.S., Birch, W.D., Gilbert, M.C., Grice, J.D., Hawthorne, F.C., Kato, A., Kisch, H.J., Krivovichev, V.G., Linthout, K., Laird, J., Mandarino, J.A., Maresch, W.V., Nickel, E.H., Rock, N.M.S., Schumacher, J.C., Smith, D.C., Stephenson, N.C.N., Ungaretti, L., Whittaker, E.J.W., and Youzhi, G., 1997, Nomenclature of the amphiboles-Report of the subcommittee on amphiboles of the International Mineralogical Association, Commission on New Minerals and Mineral Names: American Mineralogist, v. 82, p. 1019-1037.

Meeker, G.P., Bern, A.M., Brownfield, I.K., Lowers, H.A., Sutley, S.J., Hoefen, T.M., and Vance, J.S., 2003, The composition and morphology of amphiboles from the Rainy Creek Complex, near Libby, Montana: American Mineralogist, v. 88, p. 1955-1969. 
Syracuse Research Corporation, 2005, Quantification of asbestos in soil by SEM/EDS: Prepared by Syracuse Research Corporation, North Syracuse, New York, October 28, 2005.

U.S. Environmental Protection Agency, 2008, Phase I general study design for the Libby Asbestos Superfund Site evaluation of "Low-Level" Libby Amphibole in soils inside and outside the Libby Valley: Prepared by the U.S. Environmental Protection Agency, Region 8, Denver, Colo. [With technical assistance from Syracuse Research Corporation, June 30, 2008.] 